\title{
Granulomatous Reactions Induced by Lipids Extracted from Fonsecaea pedrosoi, Fonsecaea compactum, Cladosporium carrionii and Phialophora verrucosum
}

\author{
By CÉLIO L. SILVA ${ }^{1 *}$ AND SERPUI M. EKIZLERIAN ${ }^{2}$ \\ ${ }^{1}$ Department of Parasitology, Microbiology and Immunology, School of Medicine of Ribeirão \\ Preto, University of São Paulo, 14100 Ribeirão Preto, SP, Brazil \\ 2 Department of Immunology, Biomedical Sciences Institute, University of São Paulo, São Paulo, \\ Brazil
}

(Received 16 May 1984 ; revised 24 August 1984)

Granulomatous reactions induced by lipid extracts from the dermatophyte fungi Fonsecaea pedrosoi, Fonsecaea compactum, Cladosporium carrionii and Phialophora verrucosum, the causal organisms of chromoblastomycosis, were studied. Charcoal particles coated with the lipid extracts were prepared and injected intravenously into mice. Inflammation was characterized by an intense mononuclear cell infiltrate that lodged in the lung from 4 to $8 \mathrm{~d}$ after inoculation.

\section{INTRODUCTION}

Chromoblastomycosis or verrucose dermatitis is a chronic mycotic infection which occurs in humans and animals and is usually limited to the skin and subcutaneous tissue (Greer et al., 1979). This disease has a world-wide distribution but the great majority of cases occur in tropical or subtropical regions, especially where the climate is hot and humid. Most cases are seen in male agricultural workers, who are nearly always in the $30-50$ years age group. Spores are probably implanted in small wounds on the feet and legs (Vollum, 1977).

The disease is caused by a wide variety of closely related pigmented fungi which produce black or brown thick-walled spores in tissue and dark growths in culture. Five species of dermatophyte fungi, Fonsecaea pedrosoi, Fonsecaea compactum, Cladosporium carrionil, Phialophora verrucosum and Phialophora dermatitidis, are the main causative agents of this disease.

The lesions produced by these fungi may be of dry verrucose or moist vegetative type (Romero $\&$ Trejos, 1953). They develop as small pink scaly papules, often at the site of trauma to the skin, and enlarge to warty tumours which may remain or spread out to form plaques. The plaques may be verrucose with central scarring, extensively scarred with a serpiginous border, scaly or indurated with fistulae. In the later stages of infection, dissemination may occur by extension of the lesions as satellites along the lymph vessels or by autoinoculation through scratching. The main complication is secondary infection, which may be frequent and lead to gross lymphoedema and elephantiasis.

The cystic form of chromoblastomycosis is being recognized with increasing frequency. A small nodular lesion on an exposed part of the body becomes centrally necrotic and a firm subcutaneous cyst about $2 \mathrm{~cm}$ in diameter forms. When observed under the microscope, the cyst is composed of an external layer of fibrous tissue and an internal layer of thick granulomatous inflammatory tissue containing polymorphonuclear leucocytes, histiocytes and multinucleated giant cells (Iwatsu \& Miyaji, 1978). Brown yeast cells and Langhans-type giant cells may be seen in and around the foreign body.

Studies on pathogenic fungi suggest that several factors determine their pathogenicity. The most frequently mentioned are lipids (Peck, 1947) and cell wall polysaccharides (San-Blas, 
1982). Despite the relative frequency of chromoblastomycosis, little is known about the lipid components of chromoblastomycosis agents, or about the host-parasite relationship.

The development of a model of pulmonary inflammatory reaction has permitted the study of several components relevant to host defences and pathogen virulence in both respiratory disease and schistosomiasis (Boros \& Warren, 1971; Von Lichtenberg et al., 1971). In particular, the experimental introduction into the mouse lung of mycobacterial glycolipid ('cord factor'; Noll \& Bloch, 1956) adsorbed to charcoal particles has provided a useful method for investigation of the inflammatory reaction elicited by this compound around the particles (Silva et al., 1983).

Lipid compounds analogous to 'cord factor' have not been found in human pathogenic fungi. This, however, does not exclude the possible participation of other classes of lipid substances in the chronic evolution of fungal disease.

The results presented here show that a chronic inflammatory reaction is evoked in lungs of mice inoculated with lipid extracts of dermatophyte fungi adsorbed to charcoal particles.

\section{METHODS}

Fungal strains and cultures. Fonsecaea pedrosoi M-364, Fonsecaea compactum 174, Cladosporium carrionii 370, Phialophora verrucosum M-173, and Candida albicans were obtained from Dr Arlete M. Cury, Faculty of Pharmaceutical Sciences, University of São Paulo, Brazil. All strains were cultured at $22^{\circ} \mathrm{C}$ for $14 \mathrm{~d}$ in medium containing ( $\mathrm{g}^{-1}$ in distilled water) glucose, 20; peptone, 10; and yeast extract, 1 . The fungi were washed seven times with distilled water and lyophilized.

Lipid extraction. The lyophilized cultures were suspended in 15 vols of a chloroform $/$ methanol $(1: 1, v / v)$ mixture and stirred with a magnetic stirrer for $1 \mathrm{~h}$. The extracts were separated by centrifugation at $5000 \mathrm{~g}$ for $5 \mathrm{~min}$ and the insoluble residues, resuspended in the same solvent system as described above, were subjected to ultrasonic vibration (Labsonic 1510; Braun, Melsungen, FRG) at $100 \mathrm{~W}$ for $5 \mathrm{~min}$ and re-extracted three more times as described. The extracts were combined and reduced to dryness on a rotary evaporator. Diethyl ether-soluble lipids, obtained as previously described (Silva \& Ioneda, 1977a), were stored under vacuum in a desiccator.

Purification of diethyl ether extracts by chromatography. Each extract $(0 \cdot 1 \mathrm{~g})$ was dissolved in a small volume of chloroform and loaded on a $0.9 \times 10 \mathrm{~cm}$ column of silicic acid (Carlo Erba code 41000)/silica gel $(60 \mathrm{H}$; Merck) $(50 \%, w / w)$. The column was eluted with $50 \mathrm{ml}$ each of the following solvents: chloroform; $5 \%(v / v)$ ethanol in chloroform; $60 \%(\mathrm{v} / \mathrm{v})$ acetone in chloroform; acetone; $20 \%(\mathrm{v} / \mathrm{v})$ methanol in chloroform; and methanol alone. The lipid fractions obtained by chromatographic fractionation were analysed by thin-layer chromatography (TLC). The following solvent systems were used: solvent $\mathrm{A}, n$-hexane/diethyl ether/acetic acid $(83: 16: 1$, by vol.) and solvent B, chloroform/acetone/methanol/water $(50: 60: 2 \cdot 5: 3$, by vol.). Lipids on TLC plates (plastic sheets coated with silica gel F254, Merck) were detected by exposure to iodine vapour. Phospholipids were detected with molybdenum-blue spray reagent (Kates, 1972) and sugar-containing lipids were revealed with anthrone/sulphuric acid (Silva \& Ioneda, 1977b).

Preparation of cord factor from $B C G$. One hundred grams of heat-killed wet BCG (Moreau strain) was repeatedly extracted with a mixture of chloroform/methanol $(1: 1$, by vol.) and the extracted material $(20.5 \mathrm{~g})$ was fractionated by column chromatography on a mixture of silicic acid/silica gel $\mathrm{H}$ according to the method described by Silva $e t$ al. (1979) for the purification of dimycoloyltrehalose from Nocardia asteroides, Nocardia farcinica, Gordona lentifragmenta and Gordona bronchialis. The purified glycolipid $(0.65 \mathrm{~g})$ had $[\alpha]_{\mathrm{D}}^{25}+47\left(\mathrm{c} 0.5\right.$ in $\left.\mathrm{CHCl}_{3}\right) ;$ melting point at $58{ }^{\circ} \mathrm{C} ; 11 \%$ sugar content determined by the phenol/sulphuric acid method (Dubois et al., 1956) and an infrared spectrum similar to those described for dimycoloyltrehalose isolated from Mycobacterium tuberculosis (Lederer, 1976), Nocardia (Silva et al., 1979) and Corynebacterium (Ioneda \& Silva, 1979). After alkaline hydrolysis (Ioneda et al., 1963), trehalose and mycolic acid were identified in the aqueous and ethereal phases, respectively. Physical and chemical analysis of the isolated mycolic acid (Thomas et al., 1979) showed the carbon chain length centred in $\mathrm{C}_{84}$ in agreement with previously reported results (Minnikin et al., 1983).

Lipids adsorbed to charcoal particles. Five grams of activated charcoal particles (Merck) were added to $300 \mathrm{ml}$ distilled water, homogenized with a magnetic stirrer and allowed to sediment for $5 \mathrm{~min}$. The supernate containing small particles was collected and centrifuged at $5000 \mathrm{~g}$ and the deposited particles, which ranged in size from 50 to $150 \mu \mathrm{m}$ diameter, were vigorously washed for $10 \mathrm{~min}$ with absolute ethanol to remove impurities. The particles were allowed to settle, the supernate was discarded and the same washing procedure was repeated five times. Finally the particles were heated at $100^{\circ} \mathrm{C}$ for $1 \mathrm{~h}$, weighed and stored. Different amounts of this charcoal powder $(2.5-25 \mathrm{mg}$ ) were placed in separate $15 \mathrm{ml}$ glass tubes and $1 \mathrm{ml}$ of the appropriate chloroform lipid solution $\left(225 \mu \mathrm{g} \mathrm{ml}^{-1}\right)$ was added to each tube. The tubes were warmed to $40^{\circ} \mathrm{C}$ and the solvent removed with a vigorous stream of nitrogen. Saline $(1.0 \mathrm{ml})$ was then added to each tube and the charcoal particles were redispersed by sonication for 2 to $3 \mathrm{~min}$ at $100 \mathrm{~W}$ using a $9 \mathrm{~mm}$ titanium probe (Labsonic 1510 ; Braun). The suspension was cen- 
trifuged and the particles were washed repeatedly until the supernate gave a negative colorimetric reaction for lipids (Biolab Merieux kit). Lipids bound to charcoal particles were quantitatively analysed by the method described above after extraction with ethyl ether containing $1 \%(\mathrm{v} / \mathrm{v}) 12 \mathrm{M}-\mathrm{HCl}$. The number of particles in each preparation was counted in a Neubauer chamber.

Animals. Male Swiss albino mice 4 to 6 weeks old and weighing 20 to $25 \mathrm{~g}$ were used.

Induction of the lesions. The granulomagenic property of the extracted lipids was tested by intravenous injection of $9 \times 10^{5}$ lipid-coated charcoal particles through the retro-orbital venous plexus. Uncoated particles, as well as particles coated with lipid extract from Candida albicans and cord factor from BCG, were used as controls. At different times after the intravenous injection of charcoal particles, five animals per group were anaesthetized with ether and killed by exsanguination. Their lungs were fixed by the infusion of $2 \mathrm{ml}$ Bouin's fixative into the exposed trachea. The fixed organs were sectioned through the hilus and histologic sections were made of different areas of both lungs. Slides were evaluated as follows: 100 to 200 particles were scored; particles with no inflammation or with a very mild reaction, usually with less than two layers of cells surrounding the particles, were considered negative: $2+, 3+$ reactions were those composed of more than five and eight layers of cells, respectively.

\section{RESULTS}

Cells $(2 \mathrm{~g})$ of $F$. pedrosoi, $F$. compactum, $C$. carrionii and $P$. verrucosum, collected by filtration from culture media were extracted several times with chloroform/methanol (1:1, by vol.) and the diethyl ether-soluble lipids, accounting for respectively $9 \cdot 6,8 \cdot 4,10 \cdot 2$ and $9 \cdot 2 \%$ of cell dry weight, were obtained.

The charcoal particles coated with lipid extracts were homogeneous in size when observed under the microscope. When different amounts of particles were mixed with a lipid solution, the ratio $\mu \mathrm{g}$ lipid per $\mathrm{mg}$ charcoal particles remained constant, suggesting that the lipid had saturated the particle surface (Table 1). Considering that $5 \mathrm{mg}$ charcoal powder adsorbed $51.5 \mu \mathrm{g}$ lipid extract and that in this amount of charcoal powder there were $9.1 \times 10^{6}$ particles, it was estimated that each particle had adsorbed $5.7 \times 10^{-6} \mu \mathrm{g}$ lipid.

Intravenous inoculation of diethyl ether-soluble lipids extracted from $F$. pedrosoi, $F$. compactum, $C$. carrionii and $P$. verrucosum into mice in the form of coated charcoal particles induced intense inflammatory reactions around the particles trapped in their lungs (Fig. 1). These inflammatory reactions were most intense at 4 to $8 \mathrm{~d}$. At this time about $70 \%$ of particles coated with $F$. pedrosoi lipid induced inflammation. In contrast, strong granulomatous reactions were induced on over $50 \%$ of particles coated with C. carrionii lipid, $45 \%$ of particles coated with $F$. compactum lipid and $40 \%$ of particles coated with $P$. verrucosum lipid. In the case of both particles coated with lipid extract from Candida albicans and uncoated particles, $99 \%$ were scored as negative at 2, 4 and $8 \mathrm{~d}$ post-injection. Cord factor isolated from Mycobacterium bovis $(B C G)$ induced a strong inflammatory reaction $(3+)$ on $100 \%$ of particles.

Table 1. Coating of charcoal particles with lipid extracted from $F$, pedrosoi

\begin{tabular}{|c|c|c|c|c|c|c|}
\hline $\begin{array}{l}\text { Lipid } \\
\text { extract } \\
\text { added } \\
(\mu \mathrm{g})\end{array}$ & $\begin{array}{l}\text { Amount } \\
\text { of } \\
\text { charcoal } \\
(\mathrm{mg})\end{array}$ & $\begin{array}{l}\text { Lipid } \\
\text { bound } \\
(\mu \mathrm{g})^{*}\end{array}$ & $\begin{array}{l}\text { Unbound } \\
\text { lipid } \\
(\mu \mathrm{g})\end{array}$ & $\begin{array}{c}\text { Ratio } \\
\mu \mathrm{g} \text { bound } \\
\text { lipid/ } \\
\text { mg charcoal }\end{array}$ & $\begin{array}{c}\text { Efficiency } \\
(\%)^{\dagger}\end{array}$ & $\begin{array}{l}10^{-6} \times \\
\text { No. of } \\
\text { charcoal } \\
\text { particles }\end{array}$ \\
\hline 225 & $2 \cdot 5$ & $23.9 \pm 1 \cdot 3$ & $199 \cdot 0$ & $9 \cdot 5$ & $10 \cdot 6$ & $4 \cdot 5$ \\
\hline 225 & $5 \cdot 0$ & $51.5 \pm 2.5$ & $167 \cdot 7$ & $10 \cdot 3$ & $22 \cdot 8$ & $9 \cdot 1$ \\
\hline 225 & $7 \cdot 5$ & $74.5 \pm 1.4$ & $151 \cdot 2$ & $9 \cdot 9$ & $33 \cdot 1$ & $13 \cdot 6$ \\
\hline 225 & $10 \cdot 0$ & $92.5 \pm 2.2$ & $125 \cdot 2$ & $9 \cdot 2$ & $41 \cdot 1$ & $17 \cdot 8$ \\
\hline 225 & $15 \cdot 0$ & $137.5 \pm 2.8$ & $83 \cdot 3$ & $9 \cdot 2$ & $61 \cdot 1$ & $27 \cdot 7$ \\
\hline 225 & $20 \cdot 0$ & $189.0 \pm 2.9$ & $33 \cdot 5$ & $9 \cdot 5$ & $84 \cdot 0$ & $37 \cdot 0$ \\
\hline 225 & $25 \cdot 0$ & $221.5 \pm 1.0$ & $0 \cdot 0$ & $8 \cdot 9$ & $98 \cdot 4$ & $44 \cdot 0$ \\
\hline 225 & $30 \cdot 0$ & $223 \cdot 2 \pm 3 \cdot 1$ & $0 \cdot 0$ & $7 \cdot 4$ & $99 \cdot 2$ & $53 \cdot 2$ \\
\hline
\end{tabular}

* Results are mean \pm SD of five experiments.

+ The efficiency of coating is expressed as the percentage of total lipid extract added which is bound to the charcoal. 


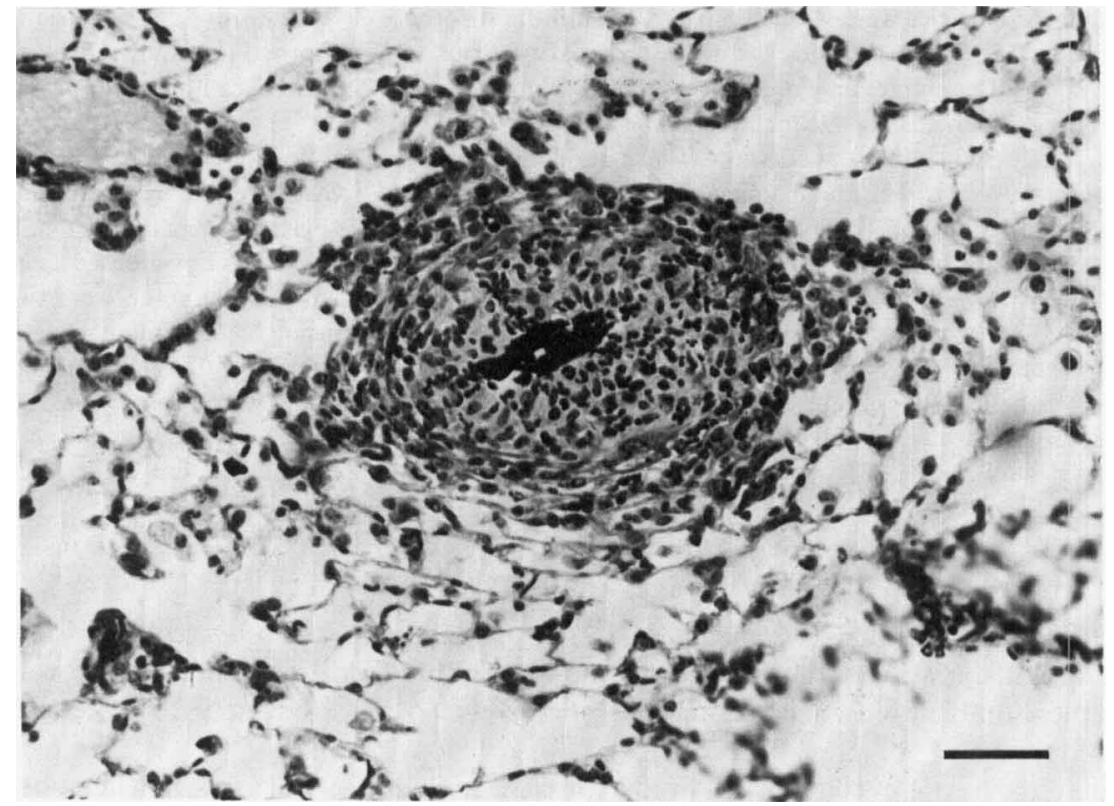

Fig. 1. Histology of lung from a mouse injected with charcoal particles coated with diethyl ether-soluble lipids extracted from $F$. pedrosoi. Note strong granulomatous reaction (3+) $4 \mathrm{~d}$ post-injection. Bar, $20 \mu \mathrm{m}$.

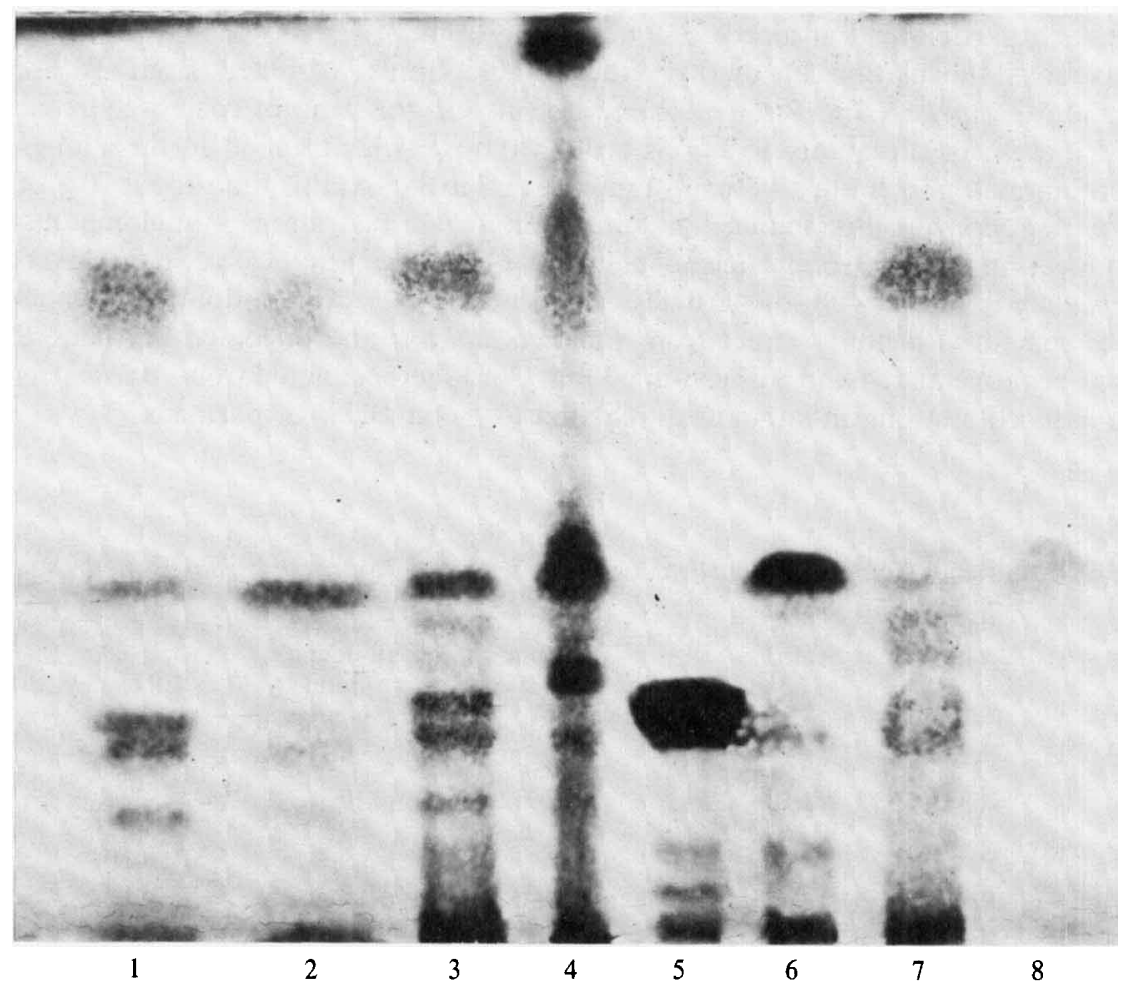

Fig. 2. Thin-layer chromatography of lipid extracts isolated from: $F$. pedrosoi (1), $F$. compactum (2), $C$. carrionii (3), BCG (4) and P. verrucosum (7). Cholesterol (5) and stearic (6) and palmitic (8) acid were used as reference. Solvent, $n$-hexane/diethyl ether/acetic acid $(83: 16: 1$, by vol.); detection, iodine vapour. 
Table 2. Fractionation of granulomagenic lipid extracts by column chromatography on silicic acid/silica gel

\begin{tabular}{|c|c|c|c|c|c|c|c|}
\hline Organism & $\begin{array}{l}\text { Eluting } \\
\text { solvent* }\end{array}$ & $\begin{array}{l}\text { Percentage } \\
\text { of total } \\
\text { lipid }\end{array}$ & $\begin{array}{l}\text { No. of } \\
\text { spots } \\
\text { by TLC }\end{array}$ & $\begin{array}{l}\text { Sugar } \\
\text { content } \\
(\mathrm{mg} \%)\end{array}$ & $\begin{array}{l}\text { Phosphorus } \\
\text { content } \\
\text { (mg \%) }\end{array}$ & $\begin{array}{c}\text { Hydrosoluble } \\
\text { compound } \\
\text { released after } \\
\text { alkaline } \\
\text { hydrolysis } \dagger\end{array}$ & $\begin{array}{c}\text { Major lipid } \\
\text { class } \\
\text { present } \ddagger\end{array}$ \\
\hline$F$. pedrosoi & $\begin{array}{l}\mathrm{C} \\
\text { CE5 } \\
\text { CA60 } \\
\text { A } \\
\text { CM20 } \\
\text { M }\end{array}$ & $\begin{array}{r}29 \\
35 \\
14 \\
2 \\
8 \\
12\end{array}$ & $\begin{array}{l}7 \\
4 \\
3 \\
2 \\
3 \\
4\end{array}$ & $\begin{array}{r}2 \cdot 5 \\
5 \cdot 2 \\
18 \cdot 3 \\
12 \cdot 0 \\
6 \cdot 3 \\
7 \cdot 2\end{array}$ & $\begin{array}{l}- \\
- \\
- \\
- \\
0 \cdot 5 \\
0 \cdot 6\end{array}$ & $\begin{array}{l}\text { Glyc } \\
\text { Glyc } \\
\text { Glc, Glyc } \\
\text { Gle, Glyc } \\
\text { Glyc } \\
\text { Glyc, Inos }\end{array}$ & $\begin{array}{l}\text { TG, DG, MG, CO, FA } \\
\text { DG, MG, FA, GL } \\
\text { GL, MG } \\
\text { GL } \\
\text { DPG, PC } \\
\text { DPG, PC, PE, PI }\end{array}$ \\
\hline F. compactum & $\begin{array}{l}\mathrm{C} \\
\mathrm{CE} 5 \\
\mathrm{CA} 60 \\
\mathrm{~A} \\
\mathrm{CM} 20 \\
\mathrm{M}\end{array}$ & $\begin{array}{r}20 \\
30 \\
12 \\
4 \\
14 \\
20\end{array}$ & $\begin{array}{l}6 \\
4 \\
3 \\
3 \\
3 \\
4\end{array}$ & $\begin{array}{r}1 \cdot 6 \\
3 \cdot 2 \\
12 \cdot 8 \\
7 \cdot 4 \\
6 \cdot 3 \\
5 \cdot 4\end{array}$ & $\begin{array}{c}- \\
- \\
- \\
0 \cdot 1 \\
0 \cdot 4 \\
0 \cdot 6\end{array}$ & $\begin{array}{l}\text { Glyc } \\
\text { Glyc, Glc } \\
\text { Glyc, Glc } \\
\text { Glyc } \\
\text { Glyc } \\
\text { Glyc, Inos }\end{array}$ & $\begin{array}{l}\text { TG, DG, MG, CO, FA } \\
\text { DG, MG, FA } \\
\text { MG, GL } \\
\text { DPG, GL } \\
\text { DPG, PC } \\
\text { DPG, PC, PE, PI }\end{array}$ \\
\hline C. carrionii & $\begin{array}{l}\mathrm{C} \\
\text { CE5 } \\
\text { CA60 } \\
\text { A } \\
\text { CM20 } \\
\text { M }\end{array}$ & $\begin{array}{r}25 \\
28 \\
10 \\
5 \\
16 \\
16\end{array}$ & $\begin{array}{l}7 \\
4 \\
3 \\
3 \\
4 \\
4\end{array}$ & $\begin{array}{r}2 \cdot 4 \\
2 \cdot 2 \\
13 \cdot 0 \\
8 \cdot 2 \\
3 \cdot 6 \\
4 \cdot 2\end{array}$ & $\begin{array}{l}- \\
- \\
- \\
- \\
0 \cdot 4 \\
0 \cdot 5\end{array}$ & $\begin{array}{l}\text { Glyc } \\
\text { Glyc } \\
\text { Glyc } \\
\text { Glyc } \\
\text { Glyc } \\
\text { Glyc }\end{array}$ & $\begin{array}{l}\text { TG, DG, MG, CO, FA } \\
\text { MG, FA } \\
\text { MG, FA, GL } \\
\text { GL } \\
\text { DPG } \\
\text { DPG, PC, PE }\end{array}$ \\
\hline P. verrucosum & $\begin{array}{l}\mathrm{C} \\
\mathrm{CE} 5 \\
\mathrm{CA} 60 \\
\mathrm{~A} \\
\mathrm{CM} 20 \\
\mathrm{M}\end{array}$ & $\begin{array}{r}22 \\
30 \\
16 \\
2 \\
12 \\
18\end{array}$ & $\begin{array}{l}7 \\
4 \\
3 \\
3 \\
3 \\
4\end{array}$ & $\begin{array}{r}1.7 \\
1.9 \\
15 \cdot 5 \\
8.6 \\
3.4 \\
5.6\end{array}$ & $\begin{array}{l}- \\
- \\
- \\
- \\
0 \cdot 5 \\
0 \cdot 6\end{array}$ & $\begin{array}{l}\text { Glyc } \\
\text { Glyc } \\
\text { Glyc, Glc } \\
\text { Glyc } \\
\text { Glyc } \\
\text { Glyc, Inos }\end{array}$ & $\begin{array}{l}\text { TG, DG, MG, CO, FA } \\
\text { DG, MG, FA } \\
\text { MG, FA, GL } \\
\text { GL } \\
\text { DPG, PC } \\
\text { DPG, PE, PI, PE }\end{array}$ \\
\hline
\end{tabular}

* C, chloroform; CE5, $5 \%$ ethanol in chloroform; CA60, $60 \%$ acetone in chloroform; A, acetone; CM20, $20 \%$ methanol in chloroform; M, methanol.

† Glyc, glycerol; Glc, glucose; Inos, inositol.

¥ TG, triglyceride; DG, diglyceride; MG, monoglyceride; CO, cholesterol; FA, fatty acid; GL, glycolipid; DPG, diphosphatidylglycerol; PC, phosphatidylcholine; PE, phosphatidylethanolamine; PI, phosphatidylinositol.

Histologically, the inflammatory reactions to all coated particles were similar. The early reactions were characterized by regular layers (usually 5 to 10) of large mononuclear and polymorphonuclear cells. The mononuclear cells exhibited the typical morphology of macrophages. Twelve days after the injection of particles, the histology changed; the granulomas were smaller, and the cells were more tightly packed, with a tendency to stack in a more organized fashion and form epithelioid-type cells. No inflammatory reactions were observed in lungs taken at $24 \mathrm{~d}$.

The granulomagenic lipid extracts contained several components as shown by TLC in solvent A (Fig. 2), and were therefore fractionated by column chromatography on silicic acid/silica gel. The fractions eluted from the column were analysed by TLC in solvents A and B (described in Methods). The same lipid pattern was observed in all extracts studied (Table 2). Neutral lipids (mono-, di- and triglycerides, cholesterol, free fatty acids and esters of fatty acids) were recovered from the column with chloroform; mixtures of free fatty acids and monoglycerides were eluted with $5 \%(\mathrm{v} / \mathrm{v})$ ethanol in chloroform; glycolipids with $60 \%(\mathrm{v} / \mathrm{v})$ acetone in chloroform and with acetone and, finally, phospholipids with $20 \%(\mathrm{v} / \mathrm{v})$ methanol in chloroform and with methanol.

Intravenous injection of these eluted fractions into mice in the form of coated charcoal particles showed that lipids contained in the $60 \%$ acetone in chloroform and acetone fractions were the most active under the experimental conditions used (Table 3 ). 
Table 3. Kinetics of inflammatory reaction around particles coated with lipid fractions eluted from silicic acid/silica gel column

\begin{tabular}{|c|c|c|c|c|c|c|}
\hline \multirow{3}{*}{$\begin{array}{l}\text { Lipids } \\
\text { obtained } \\
\text { from }\end{array}$} & \multirow{3}{*}{$\begin{array}{l}\text { Eluting } \\
\text { solvent* }\end{array}$} & \multicolumn{5}{|c|}{$\begin{array}{l}\begin{array}{l}\text { Percentage of total charcoal } \\
\text { particles coated with lipid fractions } \\
\text { showing } 3+\text { inflammatory reaction }\end{array}\end{array}$} \\
\hline & & \multicolumn{5}{|c|}{ Days post-injection: } \\
\hline & & 2 & 4 & 8 & 16 & 32 \\
\hline \multirow[t]{6}{*}{ F. pedrosoi } & $\mathrm{C}$ & 10 & 5 & 1 & 1 & 0 \\
\hline & CE5 & 15 & 12 & 6 & 0 & 0 \\
\hline & CA60 & 70 & 75 & 68 & 30 & 5 \\
\hline & A & 45 & 43 & 36 & 20 & 2 \\
\hline & CM20 & 12 & 10 & 10 & 2 & 0 \\
\hline & $\mathbf{M}$ & 2 & 1 & 0 & 0 & 0 \\
\hline \multirow[t]{6}{*}{ F. compactum } & $\mathrm{C}$ & 2 & 1 & 0 & 0 & 0 \\
\hline & CE5 & 5 & 3 & 3 & 1 & 0 \\
\hline & CA60 & 55 & 50 & 32 & 12 & 2 \\
\hline & A & 25 & 19 & 7 & 3 & 0 \\
\hline & CM20 & 6 & 3 & 3 & 0 & 0 \\
\hline & $\mathbf{M}$ & 2 & 0 & 0 & 0 & 0 \\
\hline \multirow[t]{6}{*}{ C. carrionii } & $\mathrm{C}$ & 3 & 3 & 1 & 0 & 0 \\
\hline & CE5 & 15 & 10 & 2 & 0 & 0 \\
\hline & CA60 & 48 & 32 & 30 & 5 & 1 \\
\hline & A & 17 & 15 & 10 & 5 & 1 \\
\hline & CM20 & 6 & 5 & 3 & 1 & 0 \\
\hline & $\mathbf{M}$ & 5 & 5 & 1 & 0 & 0 \\
\hline \multirow[t]{6}{*}{$P$. verrucosum } & $\mathrm{C}$ & 3 & 2 & 0 & 0 & 0 \\
\hline & CE5 & 4 & 2 & 1 & 1 & 0 \\
\hline & CA60 & 56 & 48 & 30 & 12 & 0 \\
\hline & A & 26 & 25 & 12 & 6 & 1 \\
\hline & CM20 & 7 & 5 & 4 & 2 & 0 \\
\hline & $\mathbf{M}$ & 3 & 3 & 1 & 1 & 0 \\
\hline
\end{tabular}

* C, chloroform; CE5; $5 \%$ ethanol in chloroform; CA60, $60 \%$ acetone in chloroform; A, acetone; CM20, $20 \%$ methanol in chloroform; M, methanol.

$\uparrow$ Three animals per group were used. The scoring of inflammatory reaction is explained in Methods.

\section{DISCUSSION}

There are many causes of granulomatous inflammation and it can be elicited experimentally by a variety of infectious agents including fungi, mycobacteria, viruses and protozoa (Forbus, 1949).

Presumably these agents or substances have common properties which induce this response. Bloch (1950) described the isolation of a substance from Mycobacterium tuberculosis termed "cord factor', which was highly toxic for certain strains of mice and appeared to be associated with virulence of the bacilli. Recently we have shown that this lipid component $\left(6,6^{\prime}\right.$ dimycoloyltrehalose), located outside the external layer of the bacterial cell wall, can induce granuloma formation. When cord factor was adsorbed to charcoal particles and inoculated intravenously into mice, the particles were trapped in the lung microcirculation and a large granulomatous reaction developed around the lipid-coated foreign body (Silva et al., 1983).

Intravenous inoculation of lipids extracted from $P$. pedrosoi, F. compactum, $C$. carrionii and $P$. verrucosum into mice in the form of coated charcoal particles induced an intense granulomatous reaction around the particles. The active components, which were mainly glycolipids, were recovered in the $60 \%$ acetone in chloroform and acetone fractions eluted from the chromatographic column. They were identified by co-chromatography with standard lipids and by their reaction with lipid class-specific reagents. Little is known about the glycolipid components of these fungi and there is an urgent need to identify and characterize the lipid constituent that is responsible for the pathological reaction. 
Another aspect which merits consideration is the amount of lipid on the charcoal particle. Each particle adsorbed approx. $5 \mathrm{pg}$ lipid. Our results indicate not only that these substances are granulomagenic but also that they will induce reactions at low concentration, a fact that supports arguments for their participation in the genesis of the lesions in chromoblastomycosis.

The introduction of glycolipid-coated particles into the mouse evoked an acute inflammation, with influx of neutrophil and mononuclear phagocytes. Presumably these leucocytes try to engulf and destroy the foreign substances. The continued presence of the foreign substance, especially in the form of a coated charcoal particle, may stimulate mononuclear phagocytes to mature (Adams, 1976). A mature granuloma thus results, consisting predominantly of epithelioid cells. Alterations in either the intruder or the host can change this picture by superimposing additional features such as resolution, necrosis or influx of other leucocytes.

The pathological changes that develop in granulomas, specifically the persistence of the lesion under certain conditions, are not yet understood. It is possible and indeed probable that, once the macrophages cluster around the particles or fungi, the series of changes seen among the infiltrating mononuclear cells may, to a great extent, be related to the persistence of the lipid at the site of reaction. If the material is difficult to destroy and at the same time is cytolytic for macrophages, as occurs with cord factor, it may initiate a cycle of recognition, endocytosis and cell death, which would translate itself into an extensive lesion with necrosis and ulceration. Probably, the lipid components protect the micro-organisms against the host defence mechanisms.

The role of delayed hypersensitivity in inducing granulomatous inflammation has been extensively investigated by the injection of antigen-coated bentonite particles (Boros \& Warren, 1971; Von Lichtenberg et al., 1971) or antigen-coated polyacrylamide beads (Adams, 1976). Delayed hypersensitivity can greatly augment and accelerate the development of mature granulomas (Epstein, 1967). Experimental animals, sensitized to a given antigen and subsequently challenged with that antigen bound to inert particles, develop granulomas where the particles lodge. The granulomas are formed more rapidly and grow to a larger size than in non-sensitized animals challenged with particle-bound antigen or in sensitized animals challenged with particles alone.

We have studied previously the role of delayed hypersensitivity to cord factor in the induction of granulomatous inflammation (unpublished observations). Preliminary experiments showed that prior immunization did not interfere with the number, cellular characteristics or size of the granulomas. We concluded that cord factor was able to mobilize mononuclear cells to form a granuloma without the participation of the immune system.

The data presented here support the idea that the formation of the granulomatous process denoted as chromoblastomycosis in a non-sensitized host is associated with the lipid constituents of the causative fungi.

\section{REFERENCES}

Adams, D. O. (1976). Granulomatous inflammation American Journal of Pathology 84, 164-191.

BLOCH, H. (1950). Studies on the virulence of tubercle bacilli. Isolation and biological properties of a constituent of virulent organisms. Journal of Experimental Medicine 91, 197-217.

Boros, D. L. \& Warren, K. S. (1971). Specific granulomatous hypersensitivity elicited by bentonite particles coated with soluble antigens from schistosome eggs and tubercle bacilli. Nature, London 229, 200-201.

Dubois, M., Gilles, K. A., Hamilton, J., Rebers, P. A. \& SMITH, F. (1956). Colorimetric method for determination of sugars and related substances. Analytical Chemistry 28, 350-356.

Epstein, W. L. (1967). Granulomatous hypersensitivity. Progress in Allergy 11, 36-88.
Forbus, W. D. (1949). Granulomatous Inflammation. Springfield, Ill.: Charles C. Thomas Publishers.

Greer, K. E., Gross, G. P., Cooper, P. H. \& HARDING, S. A. (1979). Cystic chromomycosis due to Wangiella dermatitidis. Archives of Dermatology 115, $1433-1434$.

Ioneda, T. \& Silva, C. L. (1979). Isolation and partial characterization of esters of trehalose from Corynebacterium ovis (C. pseudotuberculosis). Chemistry and Physics of Lipids 23, 63-68.

IonedA, T., Lenz, M. \& Pudles, J. (1963). Chemical constitution of a glycolipid from Corynebacterium diphtheriae PW8. Biochemical and Biophysical Research Communications 13, 110-114.

Iwatsu, T. \& MiYajl, M. (1978). Subcutaneous cystic granuloma caused by Phialophora verrucosa. Mycopathologia 64, 165-168. 
KATES, M. (1972). Techniques of Lipidology, p. 354. Amsterdam: North-Holland Publishing Co.

LEDERER, E. (1976). Cord factor and related trehalose esters. Chemistry and Physics of Lipids 16, 91-106.

Minnikin, D. E., Minnikin, S. M., Dobson, G., Goodfellow, M., Portaels, F., van den Breen, L. \& SESARDIC, D. (1983). Mycolic acid patterns of four vaccine strains of Mycobacterium bovis BCG. Journal of General Microbiology 129, 889-891.

Noll, H. \& BloCH, H. (1956). The chemical structure of the cord factor of Mycobacterium tuberculosis. Biochimica et biophysica acta 20, 299-309.

PECK, R. L. (1947). The lipids of fungi with special references to pathogenic fungi. In Biology of Pathogenic Fungi, pp. 162-188. Edited by W. J. Nickerson. New York: Roland Press.

Romero, A. \& Trejos, A. (1953). La cromoblastomycosis en Costa Rica. Revista de biologia tropical 1, 9599.

SAN-BLAS, G. (1982). The cell wall of fungal human pathogens: its possible role in host-parasite relationship. Mycopathologia 79, 159-184.

Silva, C. L. \& IonedA, T. (1977a). Isolation and identification of menaquinone and acylglycerols in the acetone-soluble lipids from Nocardia rhodochrous. Revista de microbiologia 8, 39-42.
Silva, C. L. \& Ioneda, T. (1977b). Purification and characterization of mononocardomycoloyl-glycerol from Nocardia rhodochrous. Chemistry and Physics of Lipids 20, 217-223.

Silva, C. L., Gesztesi, J. L. \& Ioneda, T. (1979). Trehalose mycolates from Nocardia asteroides, Nocardia farcinica, Gordona lentifragmenta and Gordona bronchialis. Chemistry and Physics of Lipids 24, 17-25.

Silva, C. L., Ekizlerian, S. M. \& Mariano, M. (1983). Participação do dimicolato de trealose na formação da lesão tuberculosa. Arquivos de biologia e tecnologia 26, 271.

Thomas, D. W., Matida, A. K., Silva, C. L. \& IONEDA, T. (1979). Esters of trehalose from Corynebacterium diphtheriae : a modified purification procedure and studies on the structure of their constituent hydroxylated fatty acids. Chemistry and Physics of Lipids 23, 267-282.

Vollum, D. I. (1977). Chromomycosis: a review. British Journal of Dermatology 96, 454-458.

Von Lichtenberg, F., SMith, T. M., LuCia, H. L. \& DoUGHTY, B. L. (1971). New model for schistosome granuloma formation using a soluble egg antigen and bentonite particles. Nature, London 229, 199-200.

ZaIAS, N. (1978). Chromomycosis. Journal of Cutaneous Pathology 5, 155-164. 